\title{
Religious Character Values in the Works of Raja Ali Haji
}

\author{
Abdul Malik ${ }^{1}$, Isnaini Leo Shanty ${ }^{2}$, Fabio Testy Ariance Loren ${ }^{3}$ \\ \{ $\underline{\text { abdulmalik@umrah.ac.id }}^{1}, \underline{\text { leoshanty@umrah.ac.id }}$, fabioloren@umrah.ac.id $^{3}$ \} \\ ${ }^{1,2,3}$ Faculty of Teacher Training and Education, Raja Ali Haji Maritime University, \\ Tanjungpinang, Indonesia
}

\begin{abstract}
This study aims to determine the religious character values in the literary works of Raja Ali Haji. The process involved analyzing Syair Abdul Muluk, Gurindam Dua Belas, Thamarat al-Muhimmah, Tuhfat al-Nafis, and Syair Sinar Gemala Mestika Alam using Pierce's semiotic theory as well as the descriptive-qualitative and content analysis techniques. The findings indicated twenty religious character values in these works which consist of four semiotic classes and are related to the teachings of Islam.
\end{abstract}

Keywords: value, character, religious, Raja Ali Haji’s literary work.

\section{Introduction}

Raja Ali Haji, originally from the Riau-Lingga Kingdom, was a prominent author during the $19^{\text {th }}$ century as well as the driving force for Indonesia's intellectual awakening and the sustenance of the Malay language of the Riau Islands which served as the forerunner of the Indonesian language [1]. It is stated in Gurindam Dua Belas (Article 5, Verse 1) which is one of the works of Raja Ali Haji that "if you wish to know the people of high birth, it is reflected in their manners and speech" [2]. He assumed the role of a scholar, author, historian, and Islamic expert, and viewed cultured attitude as an enormously paramount aspect of human lives [3]. Meanwhile, even though several studies have been conducted on the religion, linguistics, history, political governance, and literature aspects of Raja Ali Haji's literary works [4], none has focused on analyzing the views of this author up to the present time.

The literary works have been consistent with the policy of Indonesia's education due to the possibility of developing the noble values in them as learning materials [5]. Moreover, inherent moral values also contribute positively to the nation's development [6]. It is also important to note that the works reflect the view of this author about social life [4] and this makes it possible to apply the character education adopted from these literary works as a hidden curriculum in all school subjects [7].

Some previous studies have focused on the values in Raja Ali Haji's literary works such as the one conducted to investigate (1) the indices of personal character, (2) its association with the teachings of Islam, and (3) its semiotic classes [8] as well as another which observed the character indices associated with the people. Therefore, this present study aims to examine another aspect contained in these literary works which focus on three main issues including the (1) index of religious character values in human relations with God, (2) semiotic class of 
religious character values in human relations with God, and (3) the relationship of these religious character values to Islamic teachings [9].

\section{The Concept of Character}

Bukhari al-Jauhari in Taj al-Salatin [10] was the pioneer of the character concept as indicated by the 14 noble values recommended which were observed to have certain characteristics including the good character which is considered to be the closest to godliness. These values lead to self-perfection in relation to human actions and prevent them from misfortune. This is in line with the argument that such character drives humans to avoid wrongdoing and helps them towards knowledge acquisition [11]. Moreover, the character in people's hearts controls their mind and allow them to distinguish between the good and the bad. It also transforms their behavior and those with good behavior shall be glorified.

The word 'heart' in Malay is the origin of the word character and is reported to be originally derived from the Arabic word [11]. Several scholars have maintained that this word has different strata of meanings which are further classified into 5 different layers. Layer 5 as the first stratum is the most outer dimension of the heart, layer 4 as the second stratum is intelligence, layer 3 as the third stratum is spiritual intelligence, layer 2 as the fourth stratum includes intellectual and spiritual acumens while layer 1 which serves as the deepest stratum is related to spiritual secrets [12].

The heart is also divided into two sides and these include the good side which means the heart is expected to be God-oriented and incessantly substantiated while the evil side requires to be conquered. Moreover, human desire also has two parts by nature and these include 1) the desire of getting oneself close to God Almighty and paradise and 2) the desire leading to fiends and abyss. It is, therefore, advised that the Almighty, paradise-oriented, strong, and viable heart needs to be sustained [11]. The relationship between the heart and character is indicated in the following figure.

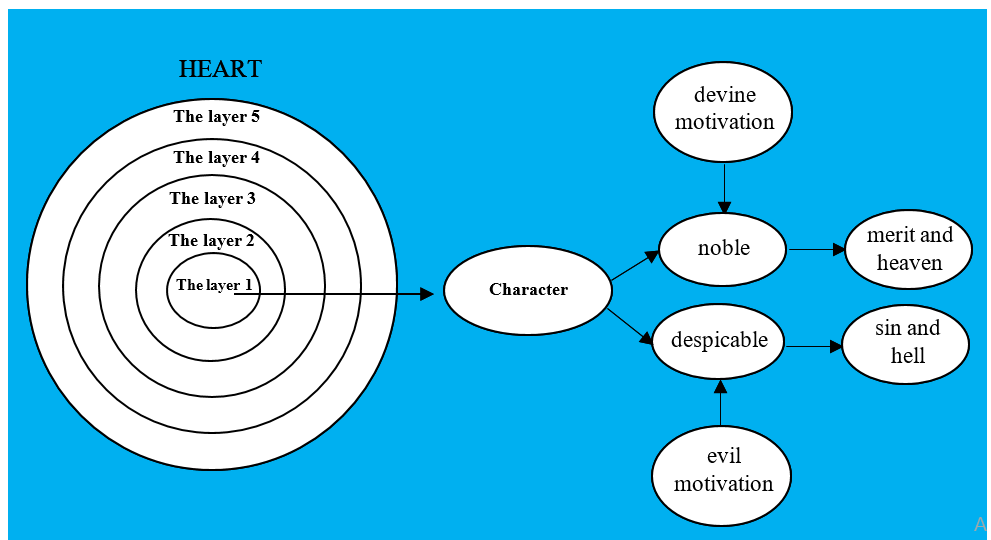

Fig. 1. The relationship between the heart and character [9].

Figure 1 shows that a good character which represents glory is derived from God-oriented desire while a bad character which generates indignity originates from evil-oriented desire. Therefore, it is important to distinguish between the bad and good character of a person. Meanwhile, this character phrase has been previously described as "complacency" [9], [13]. 
Moral philosophy or ethics also defined trait as the character or special deed of an individual which is used to express civility and respect for other people as evidenced in the demeanor and way of life of such individual. Character is also explained as the endorsement of an individual's general disposition, demeanor, decisions, ruts, and accepted moral standards, and is further referred to as a benefaction [14].

The trait is related to akhlak (morals) which is the plural form of ' $k h u l u q$ '. Meanwhile, khuluq is defined in Arabi as habits, deportment, character, demeanor, faith, nature, honor, inner outlook, or morality [15]. Moreover, Sajiyyah means deportment, mur'uah means trait, thab'in means trait, and $a d a b$ means attitude in Arabic and they all define morals. Meanwhile, despite the fact that moral is part of ethics, the two concepts are fundamentally different. This is because the pillars of belief and the pillars of Islam establish morality based on beneficence, probity, and holiness according to Islamic beliefs [14] while ethics is only associated with rationality based on the mind. It is, therefore, observed that character is semantically similar in meaning with morals because it represents a good mind with noble characteristics.

\section{Semiotic Classes}

Social events and literary works can be analyzed using semiotic theories which are very popular during the Greek Stoics era [16]. Semiotics, more particularly, is a sign-based communication theory which is normally employed in different studies. A Swiss linguist, Ferdinand de Saussure, and an American philosopher, Charles Sanders Peirce, were the pioneering semiotics scholars, and it is possible to use Peirce's triadic theory of signs to analyze classroom events in all of their semiotic complexity. Therefore, the present study used semiotics theories to analyze the personal character index due to its wide use in communication and language studies.

Every single thing can be viewed as a sign provided that it has a three-cornered relationship with the ground, denotatum, and interpretant [17]. Moreover, the representation or sign exists invariably in the triadic relationship such as soil, thing, and interpretant [18]. This means a sign is consequently perceived as an object on the side of someone or something in a particular capacity [19] and that the provision of name to a particular thing is related to the function of a sign as the 'ground'.

Denotatum represents a class in sign known as designata. Therefore, the sign is divided into three components based on its relationship with the denotatum and these include images, indices, and emblems [18]. This means the existence of a denotatum is required to determine an index which covers everything that focuses on something else such as pointing with one finger, compass direction, thrilling hmmm significantly, and the phrase deictic (there, tonight, future, and others).

A sign can be classified into 10 types based on certain differences according to Peirce [17]. The first is the qualisign also known as the rheumatic iconic qualisign which depicts color characteristics such as yellow, blue, red, white, and others. The second is the classic sinsign which denotes similarity and is observed to be synonymous with visuals, charts, maps, and mechanics. Rheumatic indexical sinsign which is the crystallization of a thing which occurs through direct experience with attention appeal in the near future is the third. This is followed by the dicent sinsign which is always indexical and informs something while the fifth is the classic legisign that informs people about a rule or law. 
It is important to note that the indexical signs also known as the existential signs are the most paramount [20]. Meanwhile, a sign can also be classified into three types and these include (1) an index referring to the truth outside the text such as the lexicon employed beyond literary works which refers to an object, minds, and others, (2) an index referring to other texts components of a script which place the text in the common literary tradition, and (3) an index referring to other elements within a text (intra-textuality). The inter-textuality and intratextuality ensure script conformance and establish its broad fiction world [20]. Moreover, objects or deportment are considered as speech deportment (parole) in a linguistic structure acting as the foundation for the grammatical analysis in the semiotic study [19].

\section{Method}

This study analyzes 5 of the 20 literary works of Raja Ali Haji including Syair Abdul Muluk (SAM) [20], Gurindam Dua Belas (GDB) [2], Tsamarat al-Muhimmah (TAM) [21], Tuhfat alNafis (TAN) [22], and Syair Sinar Gemala Mestika Alam (SGMA) [23] through a descriptive qualitative method [7]. It is important to note that the methodology is relatively complex due to the wide scope associated with delving into several works of Raja Ali Haji [24]. The content analysis (CA) technique was used to collect and analyze the data due to its ability to determine the existence of words or particular notions in a text [25]. This technique is perfect for this study because the objects under analysis are the literary works of Raja Ali Haji with the focus on describing the character indices related to the family. Moreover, the meanings and relationships of words were also analyzed based on the concept of morality proposed by Raja Ali Haji's selected works.

\section{$5 \quad$ Results and Discussion}

The value of religious character in Raja Ali Haji's literary works was found in the form of an index which is defined in Peirce's semiotic theory as a sign that is related to a cause and effect. For example, faith in God is an index of religious character values because faith is a sign which shows that someone believes in God as indicated in Islamic teachings. This indicates the belief in God is the cause while the faith in God is the effect.

The first religious character value contained in Raja Ali Haji's literary works is faith in God as observed in four works including SAM, GDB, TAM, and SGMA. Every human being is required to believe in God as the Creator of all creatures. It also shows that the absence of quality faith indicates humans are denying their existence as creatures of God. This mandate, among others, is found in the SAM, stanza 1913 which states that [26].

Barang apa pun kulihat segala

Kebesaran Tuhan Azza wa Jalla

Jikalau sungguh asal kemala

Masakan cahayanya tiada bernyala

This is part of the story on nature and attitude of the wheat handyman, Abdul Gani's helper, son of Sultan Abdul Muluk, and his wife Siti Rafiah. The grain worker firmly believes that everything happening in this world is due to the power of God and his character and attitude 
show that he has faith in God. Therefore, the verse highlights the message associated with the obligation to believe in the Creator.

GDB also contains the obligation to believe in God in the First Article, verse 3. It is discovered that the diction "to know" is used in this verse but the meaning is not just about 'knowing' but also about "believing".

Barang siapa mengenal Allah (Whosoever has knowledge of The One,)

Suruh dan tegahnya tiada ia menyalah (Command, forbid: he will not turn.)

The second line of the stanzas further emphasizes that humans are obliged to believe in God. What is the proof of that faith? There is no other proof that humans are obliged to carry out God's orders and avoid His prohibitions. This means the stanza focuses on the need to have faith in God. This mandate is further contained in verse 16 of the advice poem, TAM, [21] which is stated as follows.

Jika benar yang kita hukumkan

Di belakang jangan kita hiraukan

$U(m)$ pat dan puji kita biarkan

Kepada Allah kita saksikan

The verse implicitly conveys the message that nothing needs to be ignored in the world including praise and curse when the activities of humans are truly based on God's provisions. This means having faith in God is the most important and this can be achieved by living based on the guidelines provided by God. Moreover, all challenges need to be directed to God and this is the key to a successful life as well as the proof of human faith in God. The only condition is that every activity needs to be conducted strictly based on God's guidance without any opportunity for hidden evil by getting involved in selling the name of God which is a sin. The mandate on the obligation of humans to believe in God was also found in stanza 76 of the SGMA as indicated in the following excerpt.

Lain daripada itu beberapa pula

Suruh dan larang Allah Ta'ala

Di dalam Quran 'Azza wa Jalla

Perintahkan yang baik tiada cela

The stanza shows that all God's commands and prohibitions are only good for humans and this means they need to be believed and implemented in order to exhibit faith in God. This faith is, therefore, considered a sign of religious character in human relations with God. Meanwhile, there are twenty religious character values in Raja Ali Haji's literary works as previously explained and they are all presented in the following Table 1. 
Table 1. Religious character values in Raja Ali Haji's literary works

\begin{tabular}{|c|c|c|c|c|c|c|}
\hline \multirow[b]{2}{*}{ No. } & \multirow[b]{2}{*}{ Values } & \multicolumn{5}{|c|}{ Raja Ali Haji's Literary Works } \\
\hline & & SAM & GDB & TAN & TAM & SGMA \\
\hline 1. & Faith in God & Stanza 1.913 & $\begin{array}{l}\text { Article I, } \\
\text { stanza } 3\end{array}$ & - & Stanza 16 & Stanza 76 \\
\hline 2. & $\begin{array}{l}\text { Mentioning God's } \\
\text { name every time } \\
\text { start a work }\end{array}$ & Stanza 1 & - & p.1 & p. 21 & Stanza 1 \\
\hline 3. & $\begin{array}{l}\text { Praising God's } \\
\text { greatness }\end{array}$ & Stanza 307 & p.1 & - & p. 21 & Stanza 1 \\
\hline 4. & $\begin{array}{l}\text { Willing to accept } \\
\text { God's destiny }\end{array}$ & Stanza 684 & - & $\begin{array}{l}\text { pp. } 104- \\
105\end{array}$ & p.78 & - \\
\hline 5. & Knowing God & Stanza 204 & $\begin{array}{l}\text { Article I, } \\
\text { stanza } 3\end{array}$ & & Stanza 7 & - \\
\hline 6. & $\begin{array}{l}\text { Expecting God's } \\
\text { protection }\end{array}$ & Stanza 176 & - & - & Stanza 3 & - \\
\hline 7. & Fear of God & $\begin{array}{c}\text { Stanzas 1.241- } \\
1.333\end{array}$ & $\begin{array}{l}\text { Article III, } \\
\text { stanza } 4\end{array}$ & p. 299 & - & Stanza 58 \\
\hline 8. & $\begin{array}{l}\text { Put your trust in } \\
\text { God }\end{array}$ & Stanza 466 & $\begin{array}{l}\text { Article IV } \\
\text { stanza } 5\end{array}$ & p. 167 & Stanza 5 & $\begin{array}{l}\text { Stanzas } 53 \\
\text { and } 55\end{array}$ \\
\hline 9. & Obey worship & $\begin{array}{c}\text { Stanzas } 469- \\
470\end{array}$ & $\begin{array}{l}\text { Article X, } \\
\text { stanzas 3-4 }\end{array}$ & - & - & - \\
\hline 10. & Pray to God & Stanza 523 & - & $\begin{array}{l}\text { pp. 254- } \\
255\end{array}$ & - & - \\
\hline 11. & Expect God's help & $\begin{array}{c}\text { Stanzas 660- } \\
661\end{array}$ & - & p. 64 & - & - \\
\hline 12. & $\begin{array}{c}\text { Believing in God's } \\
\text { power }\end{array}$ & $\begin{array}{c}\text { Stanzas 500- } \\
510\end{array}$ & $\begin{array}{l}\text { Article XI, } \\
\text { stanza } 4\end{array}$ & p. 168 & - & - \\
\hline 13. & Give thanks to God & Stanza 476 & $\begin{array}{c}\text { Article V, } \\
\text { stanza 2; } \\
\text { Article } \\
\text { VIII, } \\
\text { stanza } 3\end{array}$ & p. 167 & - & - \\
\hline 14. & $\begin{array}{l}\text { Struggling to } \\
\text { uphold God's } \\
\text { religion }\end{array}$ & $\begin{array}{c}\text { Stanzas 636- } \\
667\end{array}$ & - & p. 291 & - & - \\
\hline 15. & $\begin{array}{l}\text { Expecting God's } \\
\text { forgiveness }\end{array}$ & $\begin{array}{c}\text { Stanzas 470- } \\
471\end{array}$ & $\begin{array}{l}\text { Article X, } \\
\text { stanzas 5-6 }\end{array}$ & - & - & - \\
\hline 16. & $\begin{array}{l}\text { Patiently accepting } \\
\text { God's trials }\end{array}$ & Stanza 478 & $\begin{array}{l}\text { Article VI, } \\
\text { stanza } 5\end{array}$ & p. 257 & Stanza 8 & $\begin{array}{l}\text { Stanzas } 43 \\
\text { and } 45\end{array}$ \\
\hline 17. & $\begin{array}{l}\text { Loving the hereafter } \\
\text { more than the world }\end{array}$ & $\begin{array}{c}\text { Stanzas } 469- \\
493\end{array}$ & $\begin{array}{l}\text { Article XI, } \\
\text { stanzas 3-4 }\end{array}$ & - & - & - \\
\hline 18. & $\begin{array}{l}\text { Believing in God's } \\
\text { guidance }\end{array}$ & $\begin{array}{c}\text { Stanzas 500- } \\
610\end{array}$ & $\begin{array}{l}\text { Article XII, } \\
\text { stanza } 1\end{array}$ & p. 183 & - & - \\
\hline 19. & $\begin{array}{l}\text { Following God's } \\
\text { instructions }\end{array}$ & Stanza 910 & $\begin{array}{l}\text { Article I, } \\
\text { stanza } 3\end{array}$ & - & $\begin{array}{c}\text { p.34 } \\
\text { Stanza } 8\end{array}$ & - \\
\hline 20. & $\begin{array}{l}\text { Believing in the } \\
\text { perfection of God's } \\
\text { religion (Islam) }\end{array}$ & & $\begin{array}{c}\text { Article I, } \\
\text { stanza } 1\end{array}$ & & Stanza 53 & Stanza 87 \\
\hline
\end{tabular}


Table 1 shows the religious character values in Raja Ali Haji's literary works include (1) having faith in God, (2) mentioning God's name every time when starting work, (3) praising God's greatness, (4) willing to accept God's destiny, (5) knowing God, (6) expecting God's protection, (7) fearing God, (8) putting trust in God, (9) obeying and worshipping, (10) praying to God, (11) expecting God's help, (12) believing in God's power, (13) giving thanks to God, (14) struggling to uphold God's religion, (15) expecting God's forgiveness, (16) patiently accepting God's trials, (17) loving the hereafter more than the world, (18) believing in God's guidance, (19) following God's instructions, and (20) believing in the perfection of God's religion (Islam).

The semiotic theory showed that the religious character value of believing in God narrated in SAM verse 1913 is owned by the wheat craftsman. The qualities possessed by the wheat craftsman were analyzed and described using the rheumatic iconic qualisign semiotic sign class. Moreover, the value of having faith in God exhibited by the wheat baker was also described based on the actions and words of the grain worker using the rheumatic indexical sinsign semiotic sign class because it can be seen, observed, and heard by others. It was also discovered that Raja Ali Haji used GDB, TAM, and SGMA to convey the mandate associated with the obligation to believe in God. This belief was inherent in Raja Ali Haji and this indicates the rhematic iconic qualisign semiotic sign class was used to describe this value.

It is also important to note that Raja Ali Haji uses direct statements without any intermediaries in conveying the message on the value of believing in God based on the truthvalues believed by him. This value was described using the semiotic argument sign class and this means it is mandatory for every human being to believe in God according to Islamic teachings. The value was found to be the index of human religious character as a creature created by God. Moreover, the obligation is in line with the teachings of Islam as stated in the word of God in the Qur'an, as follows:

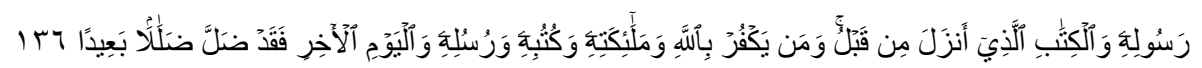

"O you who believe, keep believing in God and His Messenger and in the book which God sent down to His Messenger and in the book which God sent down before. Whoever disbelieves in God, His angels, His books, His messengers, and the Day of Judgment, then indeed that person has gone astray as far as possible" (Q.S. An-Nisa', 36).

The word of God in the Surah An-Nisa' Verse 36 of the Qur'an expressly commands believers to believe in Him and those that do not believe in God are classified as misguided. This obligation is further reinforced in the hadith of the Prophet Muhammad which states that "Islam is established on five principles: (1) testifying that there is no god (worthy of worship) except God and that Muhammad is the messenger of God, (2) establishing the five daily prayers, (3) pay zakat, (4) perform the pilgrimage to the Baitullah, (5) fast in the month of Ramadan," (H.R. Bukhari, Muslim, and Ahmad). The words of God and Prophet Muhammad cited show that believing in God is obligatory in Islam and this implies the religious character value of believing in God put forward by Raja Ali Haji is in line with the teachings of Islam. 


\section{Conclusion}

Raja Ali Haji's literary works contain 20 religious character values associated with human relationship with God which include (1) having faith in God, (2) mentioning God's name every time when starting work, (3) praising God's greatness, (4) willing to accept God's destiny, (5) knowing God, (6) expecting God's protection, (7) fearing God, (8) putting trust in God, (9) obeying and worshipping, (10) praying to God, (11) expecting God's help, (12) believing in God's power, (13) giving thanks to God, (14) struggling to uphold God's religion, (15) expecting God's forgiveness, (16) patiently accepting God's trials, (17) loving the hereafter more than the world, (18) believing in God's guidance, (19) following God's instructions, and (20) believing in the perfection of God's religion (Islam).

The index of these values consists of four semiotic classes which include rheumatic iconic qualisign, rheumatic indexical sinsign, dicent index legisign, and argument. Moreover, the values were observed to be in line with the teachings of Islam and this infers the works of Raja Ali Haji mainly originated from Islamic teachings contained in the Qur'an and Hadith. Therefore, these works can be used as a learning material for character education.

\section{References}

[1] O. Fathurahman and J. Burhanudin, "Raja Ali Haji dan bahasa Indonesia," 2008. [Online]. Available: http://www.rajaalihaji.com/id/article.php?a=RkZIL3c\%3D=. [Accessed: 24-Jan-2018].

[2] R. A. Haji, Gurindam Dua Belas. Batavia, Indonesia, 1846.

[3] N. Novianti, "Teaching character education to college students using bildungsromans," Int. J. Instr., vol. 10, no. 4, pp. 255-272, 2017.

[4] D. Lapsley, "On the prospects for Aristotelian character education," J. Moral Educ., vol. 45, no. 4, pp. 502-515, 2016.

[5] A. Bachmid, “Aktualisasi nilai-nilai Islam dalam 'Gurindam Dua Belas' karya Raja Ali Haji (Telaah teks sastra Melayu abad XIX),” J. Al-Turats, vol. 11, no. 3, pp. 201-219, 2005.

[6] Purwantini and Bramantio, "The adventure of the radical Islamic group members of the free Aceh movement in Seumpama Matahari novel: Study of genetic-structuralism," $J$. Indones. Islam, vol. 12, no. 1, p. 85, 2018.

[7] A. Imron and F. Nugrahani, "Strengthening pluralism in literature learning for character education of school students," Humanit. Soc. Sci. Rev., vol. 7, no. 3, pp. 207-213, 2019.

[8] A. Malik and I. L. Shanty, "Personal character index in the works of Raja Ali Haji," Int. J. Soc. Sci., vol. 58, no. 1, pp. 22-34, 2017.

[9] A. Malik and I. L. Shanty, "Character indexes of the people in the works of Raja Ali Haji," Adv. Soc. Sci. Educ. Humanit. Res., vol. 295, pp. 148-151, 2019.

[10] V. I. Braginskij and I. Vladimir, Erti keindahan dan keindahan erti dalam kesusasteraan Melayu klasik. Kuala Lumpur, Malaysia: Dewan Bahasa dan Pustaka, Kementerian Pendidikan Malaysia, 1994.

[11] J. D. Rahman, A. Azhar, A. Malik, A. R. Sarjono, and R. M. Hafrizal, Dermaga sastra Indonesia: Kepengarangan Tanjungpinang dari Raja Ali Haji hingga Suryatati A. Manan. Depok, Indonesia: Komodo Books, 2011.

[12] M. T. M. Yazdi, A. Ba'abud, and A. Subandi, 22 nasihat abadi penghalus budi. Jakarta: 
Citra, 2012.

[13] A. Malik, "Nilai-nilai budi pekerti dalam karya Raja Ali Haji," J. Perad. Melayu, vol. 10, pp. 96-107, 2015.

[14] M. Alfan, Filsafat etika Islam. Bandung: Pustaka Setia, 2011.

[15] S. Gazalba, Sistematika filsafat: Buku IV. Jakarta: NV Bulan Bintang, 1981.

[16] P. Cobley and L. Jansz, Introducing semiotics. New York: Icon Books-Totem Books, 1999.

[17] D. E. Hyoscyamina, "Peran keluarga dalam membangun karakter anak," J. Psikol. Undip, vol. 10, no. 2, 2011.

[18] Marzuki, Prinsip dasar akhlak mulia. Yogyakarta: Debut Wahana Yogyakarta, 2009.

[19] A. Van Zoest, Semiotika tentang tanda, cara kerjanya, dan apa yang kita lakukan dengannya. Jakarta: Yayasan Sumber Agung, 1993.

[20] S. Syamsiar, Syair Abdul Muluk. Pekanbaru: Project Section for Research and Study of Malay Culture, Research and Study of the Archipelago Culture, Ministry of Education and Culture, 1989.

[21] R. A. Haji, Tsamarat al-muhimmah. In Malik, A. (Ed.). Depok, Indonesia: Komodo Books, 2012.

[22] R. Ahmad and R. Haji, Tuhfat al-Nafis. Petaling Jaya, Malaysia: Penerbit Fajar Bakti Sdn. Bhd., 1982.

[23] H. Junus, Raja Ali Haji: Budayawan di gerbang abad XX. Pekanbaru: Unri Press, 2002.

[24] W. Trochim, Penelitian kualitatif (Translated by Diah, M.). Pekanbaru: Balai Bahasa Pekanbaru, Pusat Bahasa, Departemen Pendidikan Nasional, 2000.

[25] M. S. Stephenson, Analisis isi (Translated by Diah, M). Pekanbaru, Riau, Indonesia: Balai Bahasa Pekanbaru, Pusat Bahasa, Departemen Pendidikan Nasional, 2000.

[26] R. Haji, Tsamarat al-Muhimmah. Depok, Indonesia: Komodo Books, 1895. 